\title{
Research on Textile Enterprises to Broaden the Financing Channels
}

\author{
Minfang Gao \\ School of Management, Xi'an Polytechnic University \\ Xi'an 710048, China \\ E-mail:mfgaoxa@126.com \\ Juan Li \\ School of Management, Xi' an Polytechnic University \\ Xi'an 710048 , China \\ Tel: 15191570860 E-mail: lijuan1100@126.com \\ Qinghua Qin \\ School of Management, Xi'an Polytechnic University \\ Xi' an 710048, China \\ E-mail: qinginghuajob@sina.com
}

\begin{abstract}
Textile industry exposes many problems under financing crisis: lack of innovation, extensive growth, etc. To solve these problems, the textile industry must achieve industrial upgrading and enhance the core competence. However, the shortage of capital has restricted the development of textile industry. The paper, referring to some scholars' recommendations, discussed how to broaden financing channels to solve the current financing problems for textile enterprises.
\end{abstract}

Keywords: Textile industry, Financing channels, Financial crisis

\section{Introduction}

Textile industry plays a prominent role in Chinese economic development. However, in recent years, it experiences a series of tests such as trade friction, RMB exchange rate appreciation, considerably increasing of energy price, a gradual increase in financing costs, environmental pressures and the global financial crisis. (Ji, 2009, p.34).Especially for financial crisis, it has been in a condition of declining in benefits, increasing in losses, and financing difficulties. To solve the shortage of funds problem, many enterprises strengthened internal controls, which can not fundamentally solve the funding difficulties. Therefore, in current economic situation, broadening the financing channels is very urgent and necessary.

\section{2 .The current situation and problems of financing in textile industry}

On the one hand, external resources rely largely on debt financing, relatively, equity financing is in the condition of underdevelopment. on the other hand, internal financing which include depreciation financing and retained earnings are less than the external. (Zhang, 2008, p.15).In all, the financing channels are very simple, traditional and lack of innovation. Meanwhile, the amount is so limited that it hinders the development of textile industry. Hence, broadening the financing channels is very significant.

\section{Means of broadening financing channels}

\subsection{The special fund from the government's financial capital}

By increasing R\&D input or establishing leading brand, textile enterprises may apply for a special free fund, such as technology innovation fund. On the one hand, it eases the pressure from the insufficiency of funds. on the other, it increases the company's intangible assets and improves the company's popularity. Conversely, it benefits further financing. (Yu, 2008, p.20).

\subsection{Financing service from other corporates}

The traditional means of financing between corporates are basically limited to pre-paid accounts and business credit. In recent years, the domestic and foreign manufacturing companies carried out a number of service-oriented 
manufacturing, financing services included. For instance, Shanghai Electric's finance lease, Shaan Gu group's credit innovation, and so forth. Textile enterprises can take advantage of the financial services to expand their financing channels, by means of purchasing their products. The means is superior to lease in costs, and worth to be explored.

\subsection{Intellectual property mortgage and bank shares}

After intellectual property including patents, trademarks, copyrights are assessed and mortgaged, textile enterprises with valuable intangible assets can declare bank loans. (Duan, 2009, p.206).

Bank shares are benefit to banks and enterprises. In short term, the injections of bank's capital make enterprises tide over their difficulties. In the long term, as a shareholder, the bank can directly participate in the management and supervision directly. Meanwhile, banks can obtain good credibility and large development, and companies may finance easier due to the special status of shareholder. At present, our country still don't have corresponding policies to support this system, the government departments should guide banks and financial institutions to inject funds and hold the dominant idea 'fund to be used effectively is the only standard'. (Ren, 2008, p.211).

\subsection{Venture capital and credit cooperatives}

Capital from non-bank financial institutions have broader prospects than bank credit capital.

Venture capital is equity financing and fresh in China. Entrepreneurs in textile corporation can sell their shares to venture capitalists to obtain funds. Venture capitalists bear the risk of the enterprise's development capacity. Its operation is generally 'financing - investment - management - value added -withdraw'. But there exists some obstacles in our country, such as not forming an effective venture withdrawal mechanism yet, not having a good credibility situation in the textile industry, and entrepreneurs' reluctance to sell equity stake. Only after we solve these problems , could venture capital become the main financial channel in textile industry. (Chen, 2009, p.25).

A variety of credit cooperatives in the textile business loans play a direct, important role. It's a local 'micro-bank.' Compared with commercial banks, this financing method has the advantage of simple financing process and little restriction. Textile corporation may make well use of geographical advantages to declare some loans.

\subsection{Broadening the financial channels of private capital}

The features of private capital are quite decentralized and powerful. In recent years, the growth rate of household savings deposits is close to $15 \%$. On the one hand, many textile enterprises are faced with serious capital insufficiency; on the other, such a large capital has been idled in the bank, which is against the principle of giving priority to efficiency.

At present, there are 2,000 pawn shops in China, whose registered capital has reached 17 billions, which makes it possible to finance by pawning for the textile enterprises.

Additionally,financing from employees could raise long-term funds, and increase workers' sense of togetherness. The flexible modalities of capital return could meet emergency expenses. But this approach hasn't been paid enough attention in textile industry.There are a lot of employees in textile enterprises, which make staff financing possible. With this method, textile enterprises can get the long-term funds and strengthen the cohesion of staff.

Textile enterprises need to carry out joint-stock reform of property privatization. With such a change, the textile industry not only concentrates on construction, but gets a lot of money. According to recent investment in fixed assets and securities markets, private capital has shown an increasing interest in the acquisition of state-owned assets . (Tao, 2009, p.64).

\subsection{Gaining foreign and Hong Kong, Macao and Taiwan capital}

At present, China's textile enterprises have weak fund-raising capacity abroad. The state allows non-bank financial institutions to issue corporate bonds overseas on behalf of large companies to attain direct financing on the international capital markets, but domestic enterprises with the ability are few; which means fund is basically confined to the home and rarely involved in overseas; In addition, the number of equity financing overseas is very limited, therefore, it is necessary to broaden the financing channels in these areas, Such as listing at home and abroad, ABS(asset backed securitization)financing, (Guo, 2002, p.24).foreign funds and attracting foreign strategic investors, and so on.

\section{4 .The relevant recommendations}

It is a systematic project for textile enterprises to broadening financing channels, which demands community efforts including government, financial institutions, enterprises themselves, etc, to help textile industry get out of the woods.

Firstly, the government should reinforce construction and monitoring, and improve the domestic venture capital market, guarantee system, credit service system, enterprise fund system. Above all, no matter what innovative financing channel the textile enterprises adopt, it will ultimately return to business operations, the enterprise's internal control and governance mechanisms. Therefore, the good development of textile industry is the best guarantee for the financing. 


\section{Conclusion}

The paper mainly states some innovational financing means which textile enterprises can take under present severe financial crisis, such as special fund, the financing service, intellectual property mortgage, bank shares, venture capital, credit cooperatives, etc. It will be fairly significant for them to solve the present financing difficulties to help them ride out the storm. Meanwhile, the paper exists some deficiency about how to guarantee the implementation of the means.

\section{References}

Chen, Licun. (2009) Analysis on High-tech SMEs financing channels. Accounting communications, integration (middle), (4):25-27.

Duan Hua. (2009). Finance risk analysis and control in venture corporation. Science and technology information development and the economy. 19 (9) :206-208.

Guo Qin. (2002). Research on Financing Problem in the Textile Enterprises after Joining in the WTO. Ms D Thesis.Chengdu:Southwestern University of Finance and economics:24-28.

Ji, Haihua, Wang, Hengbin. (2009).Cost control analysis of textile enterprises under management innovation. China foreign investment, (5):34,31.

Ren, Zezhu. (2008). Countermeasures on unimpeded financing channels for SMEs in response to selection. Economist, (4): 211-212.

Tao Lian. (2009). Research on state-owned enterprises financing channels. Business culture, (4):64-65.

Yu Hua. (2008). Finance Channel Designing for Kaiyuan Corporate. Ms D Thesis.Changchun: Ji Lin University:20-22.

Zhang, Lili. (2008). Chinese Textile Corporation Finance Studies Based on the Concept of Sustainable Growth. Ms D Thesis. Tianjin:Tianjin Polytechnic University:15-23. 